\title{
Research on Ideological and Political Education of College Students From the Perspective of College Network Public Opinion
}

\author{
Wen Ren* \\ School of Marxism, Northwestern Polytechnical University, Xi'an Shaanxi, 710072, P.R.China \\ ${ }^{*}$ Corresponding author. Email: 544734758@qq.com
}

\begin{abstract}
In the era of new media, the online public opinion of colleges and universities is more complex and diverse. Formulating scientific and effective online public opinion management strategies is of great significance to maintaining the harmony and stability of colleges and universities. Through the analysis of the external social environment of the university's online public opinion, the internal environment of the university and the factors of teachers and students, as well as the study of the changes in the social environment, public opinion guidance and various emergencies, the network public opinion of the university is carried out from the perspectives of prevention, management, and guidance. The management work has strong pertinence and operability, which is conducive to strengthening ideological and political education in colleges and universities, maintaining the safety and stability of universities, and promoting the harmonious development of universities.
\end{abstract}

Keywords: College students, College network public opinion, Ideological and political education.

\section{INTRODUCTION}

In the 2013 National Propaganda and Ideological Work Conference, general secretary $\mathrm{Xi}$ Jinping emphasized that according to the development needs of the situation, the online public opinion work should be the top priority of the propaganda and ideological work. In the ideological and political work conference held at the end of 2016, general secretary Xi mentioned that it is necessary to continuously promote the development of university education in a stable and harmonious direction, so that the students at school have a sense of peace, and strengthen the education of human nature and values, and the university campus becomes a harmonious base. The network is an important part of the ideological work of universities and an important manifestation of the soft power of universities. In today's all-media communication environment, there are frequent online public opinion incidents in colleges and universities, such as the "Li Gang" case in Hebei province in 2010, the issues of Diaoyu Islands dispute in 2012, the illegal transfer of 17 postgraduate students from Hunan University in 2015, and the incident of jumping to his death from a building by a graduate student from the Wuhan University of Technology in
2018 , etc. These incidents spread rapidly through the special channel, which is the Internet. This expanded the dissemination space of information about the incident. At the same time, college students have a strong sense of participation. It is easy to connect the virtual world with the real world through the internet, and there is a tendency to synchronize online expression with offline actions. However, some colleges and universities still have some issues in dealing with online public opinion. For example, for some people, their ideological concepts are rigid and crisis awareness is weak, so they do not pay attention to online public opinion. Thus, they cannot grasp the development trend of public opinion in time, and cannot respond quickly, then public opinion crisis will occur. For another example, some people lack the ability to respond to online public opinion crises, they are at a loss when public opinion comes and the response methods are simple and rude. So, it will lead to the expansion of the situation.

Therefore, scholars at home and abroad have carried out relevant researches around the network public opinion of universities. For example, Kelling N J [1] conducted research on university network public opinion through campus surveys combined with network monitoring. Up to now, Chinese studies in this 
area has mainly focused on four aspects: concept definition, characteristics of public opinion communication, causes of public opinion and public opinion management mechanism. Currently, the number of the researches focused on the formation and evolution of public opinion in colleges and universities is relatively few, mainly formed the "three-process theory" [2], "four-stage theory" [3], and "fiveintroduction theory" [4]. Wu Susu [5] believed that the network generation logic of public opinion in colleges and universities generally experienced three periods: the period of internal public opinion, the transition period of internal public opinion to external public opinion, and the period of external public opinion. Yang Zhongying [6] used sociology, educational psychology and other related knowledges to comprehensively analyze the shortcomings of the "four stages of crisis management theory".

\section{THE CONNOTATION AND BASIC CHARACTERISTICS OF ONLINE PUBLIC OPINION IN COLLEGES AND UNIVERSITIES}

Walter Lippman, an important founder of American public opinion, pointed out in the book of Public Opinion Science that public opinion is basically a view of some facts that have been morally explained and sorted out. Internet public opinion is the "social focus" and "world hotspot" issues that netizens are concerned about (including ideology, historical evaluation, public figures, public affairs, values, etc.), which are expressed openly to the public through the network public space and the network media opinions with tendencies, strong impact and certain influence. Public opinion in colleges and universities is the specific reflection of online public opinion in colleges and universities. It is a collection of college teachers and students using the internet platform or using mobile communication technology to express their views, opinions and attitudes on campus events, such as education policies, campus life and other aspects closely related to their own interests.

Generally speaking, the public opinion cases of colleges and universities on the internet are usually caused by their own environment and social factors. The probability of occurrence of these factors is not fixed, it may be accumulated invisible, or it may be sudden. Most of them are happened on the students or caused by school management issues. And a direct effect will occur in an emergency when the case accumulates a certain scale and impact. Therefore, ideological and political workers in colleges and universities should take the initiative to analyze and judge the principles of the generation of online public opinion in colleges and universities, they should pay attention to the online public opinion of college students, they should grasp the dynamics of student public opinion, they should put the ideological and political education work in the guidance of online public opinion, and they also should guide the online public opinion of colleges and universities to conform to the mainstream ideologies. The goal is made to create a good network public opinion environment for ideological and political education.

\section{ANALYSIS OF THE CAUSES OF ONLINE PUBLIC OPINION IN COLLEGES AND UNIVERSITIES}

\subsection{Environmental Factors}

\subsubsection{The Complex Social Environment outside the University}

First is the impact of Western pluralistic values. Today's international anti-China forces attach great importance to fighting ideological wars on the Internet. They use high-tech means and bad statements to promote and sell capitalist ideology and values, and penetrate ideologically into the group of young college students in China, and they want to control public opinion and westernize young college students in China. The linkage between the virtual world and the real world made some of the vulgar information seriously impacted the mainstream socialist ideology, which greatly reduces the effectiveness of college students' ideological and political education, and also had a serious negative impact on the field of college ideology.

Second is the impact of domestic social contradictions. At present, China has entered the "deep water zone" of reform and development. The society is at a critical stage of transformation and upgrading. It can be seen that if problems occur at all levels and they are not dealt with in a timely manner, or the handling is not perfect, these problems may be various at any moment and they could be the source of many emergency cases. There is a lack of objective and rational analysis of irrational emotions in online public opinion, as well as a lack of speculative analysis. As a result, many irrational views, opinions and emotions have emerged. Whether colleges and universities are stable directly reflects the society is stable or not. College students are sensitive and enthusiastic about political thought, those who are concerned about this will use various channels to express their views.

\subsubsection{Various Problems in Universities}

On one hand, colleges and universities have many issues in the concepts, content and methods of online ideological and political education. First of all, the educational concept of network ideological and political education in colleges and universities needs to be changed urgently. Internet has a one-sided 
understanding of colleges' online public opinion when it is integrated with traditional ideological and political education in colleges and universities. The main body of online public opinion publishing are the college students, but they usually lack the study of needs of psychology. The lack of openness and innovation in the concept of educating people has caused many problems in the guidance of network public opinion in college network ideological and political education. Second, the educational content and methods of online ideological and political education in colleges and universities are relatively lagged behind. In addition, the online public opinion of colleges and universities has brought unprecedented enhancement of the subject consciousness of college students. The educational methods that emphasized simple indoctrination in the past have no longer worked. Finally, the environment for online ideological and political education in colleges and universities needs to be improved.

On the other hand, the internal management of the university is improper. The current university system has been gradually improved, and the self-awareness of university students has gradually increased. When the benefits of students are not met, and the management problems of the campus cannot be remedied in time, students' dissatisfaction will accumulate. Once emergencies fuel the flames, the students will take this opportunity to spread their emotions, which leads to many campus public opinion incidents. At the same time, the distribution of school resources is relatively unbalanced, and the decline in the quality of talent training is also one of the obvious university interior problems.

\subsection{Problems of College Students Themselves}

First, there is greater pressure on contemporary college students. College students are faced with various pressures on their life and study. For example, under the background that there is a dramatic difference of studies and life in high school and colleges, comparing with elder generations, the characteristics of the "post-00" college students are very different both in their studies and their lives from high school to college. They face various problems in colleges and universities, no matter in study or in life. It's still a matter of human affection and sophistication. If you fail to adjust your mentality in time and actively adapt to many pressures such as study and employment, it may lead to suicide and other vicious incidents.

Second, there is a complex psychology of coexistence of personality and conformity. College students are the main body of online public opinion in colleges and universities. Because of their environment and their own cultural literacy, they are willing to express their opinions. In addition, they are in a critical period of psychological maturity and have a strong sense of social responsibility and mission. They are more enthusiastic about participating in social affairs and the internal management of universities, and the network of university has become a field for them to express their personal feelings, opinions and knowledge. However, in the real society, affected by the psychology of herding, some netizens tend to inadvertently form groups that are easy to communicate. Therefore, in the face of certain events, college students have the pursuit of individuality, but their herd mentalities are also difficult to be gotten rid of. Thus, the group of college students willing to participate in the public opinion itself, but at the same time it is more difficult to establish an objective attitude.

\subsection{The Particularity of the Dissemination Path of Online Public Opinion in Universities}

\subsection{1. "Butterfly Effect"}

The "butterfly effect" is a major feature of university network public opinion. Compared with other common network public opinions, it is special and it has a deeper relationship with other related things. Therefore, it is easy to cause a phenomenon that affects the whole body. Changes may even bring about unpredictable events [7]. The spread of online public opinion can make a little-known event become well-known in a short period of time. The development of the event will increase from small to large, and the number of participants will increase from small to large. Propagation of primitive events in a dense network pattern can easily lead to the development of a single event to a multi-polar event, resulting in unpredictable changes.

\subsubsection{Spread Rumors}

Things that are arbitrarily guessed or deliberately spread based on personal imagination in order to accomplish a certain purpose are called rumors. It shows that the power of rumors is directly proportional to the importance of the incident involved, and inversely proportional to the degree of people's understanding of the incident. Once the rumor is successfully spread in public, its spread will present an extremely strong abnormal state. In this state, people continue to stimulate each other, causing the collective emotions to become excessively high and people will lose control.

\subsubsection{Unfavorable Public Opinion}

On various online platforms, the so-called "Internet Big V" are the people who are relatively well-known to netizens, they have a large number of fans and have a certain degree of influence in society. The ideas and attitudes they expressed have caused their supporters. influences. In most cases, the information transmitted by 
these "Internet Big V"s are their own value judgments, their opinions play an important role for the society in whether the society continues to progress in a good direction or the order becomes chaotic, and whether the value education of youth groups are affected. With the deepening of hot topic discussion in colleges and universities, "Internet Big V" will become an active member of campus forum and form a certain direction of public opinion. The trend of public opinion has both good and bad, but there is always bad public opinion behind the typical cases of college students' network public opinion.

\subsubsection{Emergency}

The online public opinion that appears on a university campus is like a fire that has enough fuel and things to support combustion. As long as it reaches its ignition point, it will "bang", and this ignition point usually appears in emergencies on campus.

\section{PATH SELECTION FOR IDEOLOGICAL AND POLITICAL EDUCATION IN THE CONTEXT OF ONLINE PUBLIC OPINION}

\subsection{Strengthen the Prevention and Management of Online Public Opinion in Colleges and Universities}

It is suggested to use socialist core values to guide the network public opinion of colleges and universities and build a "firewall" of network public opinion. Through the Internet, unhealthy and harmful information spreads rapidly and pervasively. The value orientation of certain online information has deviated from the mainstream values advocated by society. Thus, we must resolutely eliminate and resist it. First of all, in order to encourage college students to adhere to their ideals and beliefs, it is needed to centre on the construction of the socialist core value system, it is needed to let students at school have a clear understanding of the party's line, principles, and policies, and know how to unite and help each other as well as the country's political, economic. The knowledge of culture and other aspects allows them to understand the socialist concept of honour and disgrace, to establish a good "three outlooks", and then let them firmly believe in Marxism and socialism, and actively oppose the brainwash of diversified cultural values of the West. Second, using the latest achievements of Marxism on the road with Chinese characteristics, teachers and students have sufficient ideological and political acumen to differentiate right from wrong. They can carefully observe the outside world at anytime and anywhere, and promptly identify dangers, they can think clearly about all kinds of right and wrong questions.

It is suggested to innovate the management team training model and build an efficient and professional network public opinion management team. The network public opinion management team is the foundation and key to promote the management of network public opinion in colleges and universities and improve the effect of network public opinion management. Public opinion management in colleges and universities is a systematic work that requires the participation of many departments and personnel. In the absence of existing full-time staff, colleges and universities can employ a group of professional teachers and counselors with high political consciousness, strong student management skills, and strong network public opinion guidance capabilities through the combination of full-time and part-time teams. At the same time, it is important to strengthen their information awareness, using information technology training to cultivate their ability to use modern educational technology and improve their management capabilities. In addition, colleges and universities should give full play to the main role of students in network public opinion management and establish a team of network information officers among students. Colleges and universities can establish a team of network informants among college students who are responsible for collecting important public opinion information on the Internet, let them focus on collecting issues with tendencies in some ideological and theoretical fields and social hot issues generally concerned by college students, and information is fed back to relevant functional departments to provide accurate research and judgment references for school decision-making.

\subsection{Guide Public Opinion in a Timely Manner}

Actively instructed students on the Internet to ensure that they understand and control the trend of public opinion in time. On one hand, it is necessary to follow the current trend of social informatization to control the mainstream channels such as the Internet, and to guide college students so as not to be led astray by wrong information. On the other hand, it is important to improve the external environment of the campus, and communicate with all walks of life that are led by the press. It is also important to increase the credibility of the school, so as to avoid the appearance of online public opinion that the outside world has bad views of the school and affects the school's reputation.

Cultivate "opinion leaders" who can guide the trend of public opinion, and control the influence of public opinion in a timely manner. A world-renowned sociologist, Razafiel once said that opinions are generally informed by opinion leaders through radio, advertising and other media, and then disseminated by 
opinion leaders to relatively quiet groups. Compared with traditional public opinion leaders, online public opinion leaders have the advantages of strong technical ability, relative anonymity, and discourse dominance. During the development of online public opinion, they have a strong influence on the development and direction of online public opinion. We must pay attention to mobilizing outstanding students among students, leaders in various student organizations, influential activists among students, etc., and train them to become leaders of public opinion on campus. Whenever major public opinion occurs, those students can let people know the truth of the incident in time.

\subsection{Improving the Response Methods of Network Public Opinion Management in Colleges and Universities}

Build a normalized response mechanism to online public opinion in colleges and universities to improve crisis awareness. We should correctly understand and master the basic laws of the development of colleges and universities, establish rules and regulations, make best use of the situation, and improve the organization, monitoring and communication mechanisms of public opinion. First of all, it is necessary to strengthen the organization and guarantee mechanism of network public opinion in colleges and universities, regularly analyse network public opinion and the ideological trends of teachers and students, strengthen planning, take the initiative, and ensure campus harmony and stability. Secondly, it is necessary to use scientific and reasonable methods to collect, identify, analyse, research, early warning, feedback and public relations of public opinion information. Furthermore, improve the research and early warning mechanism of online public opinion information in colleges and universities to ensure campus network information security.

\section{CONCLUSION}

In conclusion, the online public opinion of colleges and universities is a complex but significant issue, it is of great significance to maintaining the harmony and stability of colleges and universities. In this paper, we discussed and summarized scientific and effective online public opinion management strategies. To better fulfil these strategies, we suggest establishing an early warning and processing system for online public opinion management to standardize and institutionalize public opinion management. Establish a base for handling urgent public opinions and allow more communication between various departments to enhance their collective handling of major public opinions. It is possible to build a system in which various departments headed by the network management center or the network publicity department to handle major emergencies together. The main contents include daily attention to whether emergencies occur; classification and archiving of public opinions by department at regular intervals; and monitoring of public opinions by departments; research and analyse the report. Analyse and judge public opinion that may have a negative impact in time, evaluate the risks and levels of public opinion, and improve guidance measures.

\section{REFERENCES}

[1] Kelling N J, Kelling A S, Lennon J F. The tweets that killed a university: A case study investigating the use of traditional and social media in the closure of a state university[J]. Computers in Human Behavior, 2013, 29(6): 2656-2664.

[2] $\mathrm{Hu}$ Daping. Adhere to the unification of explicit education and implicit education, and comprehensively improve the level of morality and talent cultivation in universities [J]. Ideological and Theoretical Education Guide, 2019, (07).

[3] Lin Xingfa, Yang Qian, Liu Ying. The characteristics of the formation and dissemination of online public opinion among college students[J]. Northern Economy and Trade, 2011, (2): 91-93.

[4] Zheng Sufa. Some thoughts on the research and control of network public opinion in colleges and universities[J]. Network Security Technology and Application, 2009, (9): 74-76.

[5] Wu Susu. Research on the Classification and Guidance of College Students' Public Opinion [J]. Modern Education, 2015, (2): 21-23.

[6] Yang Zhongying. The construction of the model of the decision-making system for network public opinion response to crisis events in colleges and universities[J]. School Party Building and Ideological Education, 2020, (7): 72-74.

[7] Zhang Yiting. Research on University Network Public Opinion and Crisis Management in the Information Environment[J]. Journal of Information, 2011, 30(8): 51-54. 